\title{
The large-mammal fauna from the Kibish Formation
}

\author{
Zelalem Assefa $^{\mathrm{a}, *}$, Solomon Yirga ${ }^{\mathrm{b}}$, Kaye E. Reed ${ }^{\mathrm{c}}$ \\ a Archaeobiology and Human Origins Programs, Smithsonian Institution, National Museum of Natural History, 4210 Silver Hill Road, Suitland, MD 20746-2863, USA \\ ${ }^{\mathrm{b}}$ Biology Department, Addis Ababa University, Science Faculty, P.O. Box 1176, Addis Ababa, Ethiopia \\ ${ }^{\mathrm{c}}$ Institute of Human Origins, School of Human Evolution E Social Change, Arizona State University, P.O. Box 874101, Tempe, AZ 85287, USA
}

\section{A R T I C L E I N F O}

\section{Article history:}

Received 24 April 2007

Accepted 15 May 2008

\section{Keywords:}

East Africa

Ethiopia

Extant fauna

Hylochoerus

Kibish

Middle Stone Age

Paleoecology

\begin{abstract}
A B S T R A C T
The Kibish faunal remains are useful for reconstructing the habitat of the earliest documented Homo sapiens and for understanding the community within which early modern humans existed. A diverse assemblage of large mammals, including many species of bovids, suids, and equids, has been recovered from the Kibish Formation. There are no extinct large mammals represented in the fossil assemblage, and the overall taxonomic composition of the fossil fauna is similar to the modern-day wildlife community living near the Omo River. The fossil faunal assemblage shows a paucity of arboreal primates, and carnivore species are rare. However, the faunal sample includes possible Cephalophus (duiker) remains and Hylochoerus meinertzhageni (giant forest hog), taxa that are extremely rare in the African fossil record, and both indicate more closed habitats. Comparative analyses of the Kibish faunal remains using the ecological-diversity approach document close associations with edaphic grassland and woodland vegetation types. These vegetation forms are similar to current habitats surrounding the Omo River.

(c) 2008 Elsevier Ltd. All rights reserved.
\end{abstract}

\section{Introduction}

Recent expeditions to the Kibish Formation in the Omo River Valley of southern Ethiopia (1999-2003) have yielded a sample of mammal remains that comes from all but one of the four members of the formation. Mammalian fauna is useful for reconstructing vegetation structure and for understanding the ecological associations of hominins - in this case, early Homo sapiens-with their environment, including the community in which they lived. The mammalian fauna from Kibish represents a poorly known but critical phase in the east African fossil record. According to the newly revised dates (McDougall et al., 2005, 2008), the three members of the Kibish Formation represented by mammalian fossils sample the interglacial phases of three different isotopic stages. Member I accords with isotopic stage 7 (240-200 ka), Member III with isotopic stage 5 (130-75 ka), and Member IV with the early stages of the Holocene $(<10 \mathrm{ka})$. Specifically, each of the members results from periodic episodes of high rainfall in the Ethiopian plateau that resulted in northward expansion of Lake Turkana (Butzer, 1971; Brown and Fuller, 2008; McDougall et al., 2008). The consistencies of the fauna among these three members reflect similar habitats. The depositional environments characterize the wet phases of the interglacials, as they are deltaic and littoral deposits.

\footnotetext{
* Corresponding author.

E-mail address: zassefa@gmail.com (Z. Assefa).
}

In this paper, we discuss the vegetation and fauna that exist in the Omo Valley today. This is followed by a description of the fauna recovered from the members of the Kibish Formation. We then reconstruct the paleoenvironment of the Kibish Formation based on these faunal remains and discuss the mammalian communities within which Homo sapiens fossils were recovered.

\section{Background}

Vegetation

Today the Omo Kibish area supports both wet and dry vegetation types following the course of the meandering Omo River. Closed to open woodlands dominate the inner bends of the river. The floodplains in the extended area away from the riparian woodland support open, dry habitats such as shrubland, grassland, and bushland thickets. At a larger scale, the lower Omo regional basin has an arid to semiarid tropical climate, characterized by high temperatures (Butzer, 1971) and low precipitation, with mean annual rainfall ranging from 320 to $380 \mathrm{~mm}$ and a maximum mean temperature of $40^{\circ} \mathrm{C}$ (Carr, 1976), based on records of nearby stations such as Ileret, Todenyang, and Lokomarinyang (Butzer, 1971). Although all fossil-bearing localities from the Kibish Formation come from deltaic and littoral beds on both sides of the Omo River, major sedimentary environments of the Omo Kibish area today also include crystalline uplands, pediments, and piedmont alluvia. The interaction of various soil types, topographic changes, and 
availability of moisture generally provide a mosaic of plant communities in the region, which were assigned by Carr (1976) to the broad habitat types of plains environments (grasslands), riverineassociated environments (riparian forest and woodland), and anomalous habitats (e.g., sporadic uplands and outcrops, streams, hot springs). Figure 1 shows a schematic profile of vegetation types across grasslands and riparian woodland.

Both grasslands and riverine-associated vegetation structures are dependent on soil types, rainfall, and water-drainage patterns. Higher elevations support higher plant diversity, while in the mudflats and floodplains, trees are essentially nonexistent (Carr, 1976, 1998). There are diverse mesic depositional environments, such as deltas, silt berms, levees, back swamps, and adjacent flats that also support high floral diversity. Vegetation types in the modern delta and silt berms share many similarities. The riverine woodlands occupy the natural levee crest of the river and the immediate backslope. Carr $(1976,1998)$ noted progressive shifts in the following sequences along south-to-north meanders of the river: grassland and thicket, open woodland, closed woodland, and forest. Such sequences particularly characterize levee vegetation types along inner bends of the lower $50-60 \mathrm{~km}$ of the river. Farther upstream, including the area where the Kibish Formation is exposed, the forest-cover declines and is replaced by intermediate vegetation between woodland and forest. The riverine woodlands include large trees, such as fig (Ficus sycomorus), and two major species of shrubs-gundi (Cordia sinensis) and confetti tree (Maytenus senegalensis), which are often found in association with dense thickets. The riverine forest, on the other hand, is composed of woody plants that grow to a height of $25-30 \mathrm{~m}$, and also maintain dense canopy covers. Herbs and shrubs are also found associated with the riverine forest. For a list of plant species, see Carr (1976, 1998).

Fauna

The extant and historically documented faunal composition of the Omo Kibish area is characterized by diverse taxa of large mammals (Table 1). Following Gagnon and Chew's (2000) dietarypreference assessment of extant African bovids, the species of bovids reported from the Omo area include obligate grazers, variable grazers, browser-grazer intermediates, generalists, and browsers. Thus, in its modern ecological setup, the region supports diverse species preferring both open and closed habitats (Gagnon and Chew, 2000; Cerling et al., 2003). However, grazers of both obligate and variable types appear to have higher representation among the extant bovids of the Omo Kibish area (Yalden et al., 1984). The majority of grazing species are found mainly within the different areas of grassland habitats. In the extant Omo region, there are no documented forest frugivorous/browsing bovids (i.e., cephalophines), probably indicating that the modern riverine forest is lacking in the type of fruiting plant species required to support these bovids.

The Omo Kibish area is known for one of the few sympatric distributions of Burchell's (Equus burchellii) and Grevy's zebras (Equus grevyi). Their joint presence signifies diverse precipitation and temperature ranges and a wider range of accumulated vegetation indices, distinct from the predominantly milder or harsher climates in the nonoverlapping ranges of these two equid species elsewhere (Bauer et al., 1994). The representation of two species of suids, the common warthog (Phacochoerus aethiopicus) and the bushpig (Potamochoerus porcus), is also consistent with the mosaic environments of Omo Kibish. The Omo Valley also supported the last known survivors in Ethiopia of the once widespread black rhinoceros (Diceros bicornis), which preferentially inhabits ecotones between forests and grasslands. Of the diverse species of primates documented in the Lower Omo Valley, the forest and woodland support guereza (Colobus guereza), blue monkey (Cercopithecus mitis), and De Brazza's monkey (Cercopithecus neglectus), whereas other transitional zones, as well as plains and adjacent flats, support Senegal galagos (Galago senegalensis), vervet monkeys (Chlorocebus aethiops), and anubis baboons (Papio anubis). The number of primate species inhabiting the forest today indicates the richness and lateral extent of the forest along the Omo River. Most riparian forests in semiarid regions only have Chlorocebus aethiops and occasionally Cercopithecus mitis or Colobus guereza.

\section{Materials and methods}

In the four field seasons conducted between the years 1999 and 2003, fossil fauna was collected from 122 localities sampling all

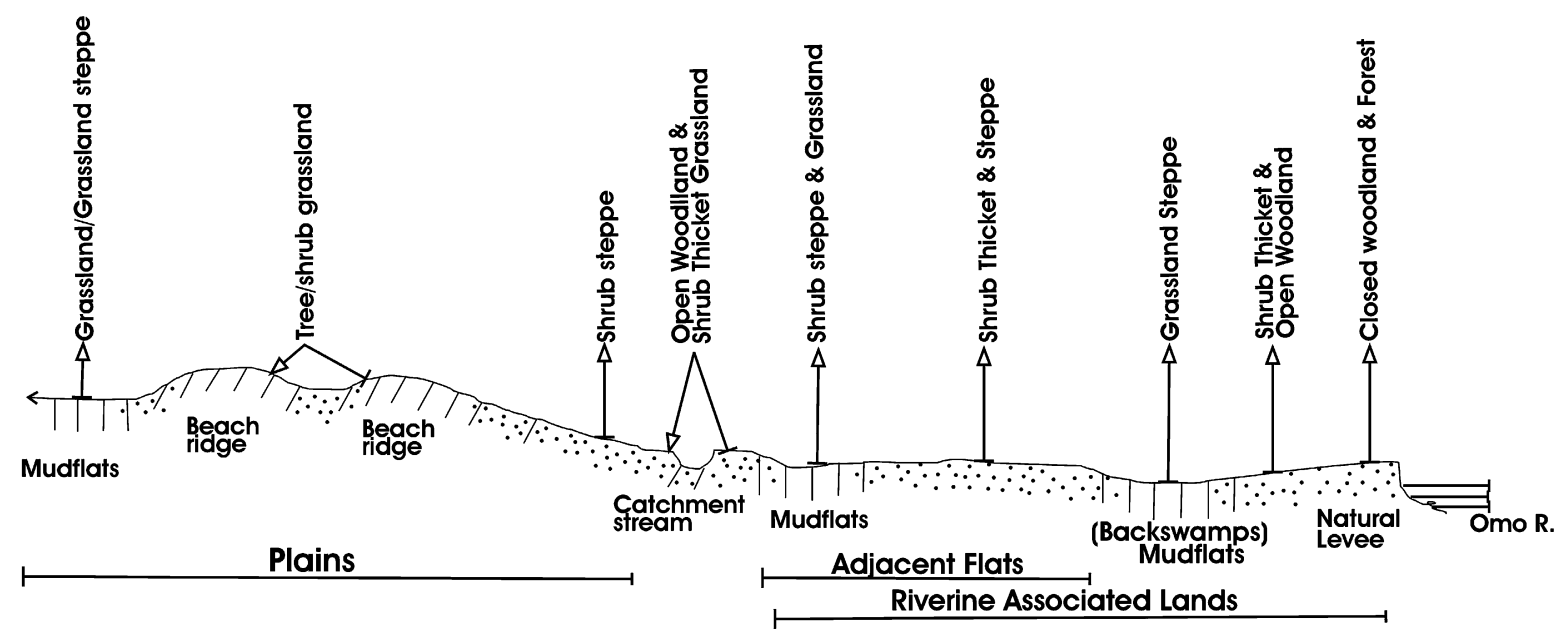

Soil Types:

$\prod \prod$ Cracking Clay

$\because \therefore \therefore$ Silt

T/T Sand

Fig. 1. Profiles of soil and vegetation types at the Lower Omo Valley (modified after Carr, 1976). 
Table 1

Extant large mammals of the Omo Kibish region.

\begin{tabular}{|c|c|c|}
\hline Family & Subfamily/tribe & Species and common names \\
\hline \multirow[t]{8}{*}{ Bovidae } & Alcelaphini & $\begin{array}{l}\text { Alcelaphus buselaphus (hartebeest) } \\
\text { Damaliscus korrigum (topi) }\end{array}$ \\
\hline & Cephalophini & Sylvicapra grimmia (bush duiker) \\
\hline & Neotragini & $\begin{array}{l}\text { Madoqua guentheri } \\
\text { smithi (Gunther's dik-dik) } \\
\text { Oreotragus oreotragus (klipspringer) } \\
\text { Ouerbia ourebi (oribi) }\end{array}$ \\
\hline & Reduncini & $\begin{array}{l}\text { Kobus ellipsiprymnus } \\
\text { defassa (waterbuck) } \\
\text { Redunca redunca (bohar reedbuck) } \\
\text { Redunca fulvorufula } \\
\text { (mountain reedbuck) }\end{array}$ \\
\hline & Antilopini & $\begin{array}{l}\text { Gazella granti (Grant's gazelle) } \\
\text { Gazella thomsonii (Thomson's gazelle) } \\
\text { Litocranius walleri (gerenuk) }\end{array}$ \\
\hline & Hippotragini & Oryx beisa (beisa oryx) \\
\hline & Tragelaphini & $\begin{array}{l}\text { Tragelaphus strepsiceros (greater kudu) } \\
\text { Tragelaphus scriptus } \\
\text { decula (bushbuck) } \\
\text { Tragelaphus imberbis (lesser kudu) } \\
\text { Taurotragus oryx (common eland) }\end{array}$ \\
\hline & Bovini & Syncerus caffer (African buffalo) \\
\hline Hippopotamidae & & $\begin{array}{l}\text { Hippopotamus amphibius } \\
\text { (river hippopotamus) }\end{array}$ \\
\hline Suidae & & $\begin{array}{l}\text { Phacochoerus aethiopicus } \\
\text { (desert warthog) } \\
\text { Potamochoerus porcus (river hog) }\end{array}$ \\
\hline Giraffidae & & $\begin{array}{l}\text { Giraffa camelopardalis } \\
\text { reticula (giraffe) }\end{array}$ \\
\hline Equidae & & $\begin{array}{l}\text { Equus grevyi (Grevy's zebra) } \\
\text { Equus burchellii } \\
\text { boehmi (Burchell's zebra) }\end{array}$ \\
\hline Rhinocerotidae & & Diceros bicornis (black rhinoceros) \\
\hline Galagidae & & Galago senegalensis (Senegal galago) \\
\hline Cercopithecidae & $\begin{array}{l}\text { Colobinae } \\
\text { Cercopithecinae }\end{array}$ & $\begin{array}{l}\text { Colobus guereza (guereza) } \\
\text { Cercopithecus mitis (blue monkey) } \\
\text { Chlorocebus aethiops (vervet monkey) } \\
\text { Cercopithecus neglectus } \\
\text { (De Brazza's monkey) } \\
\text { Papio Anubis } \\
\text { doguera (Anubis baboon) }\end{array}$ \\
\hline Elephantidae & & Loxodonta africana (African elephant) \\
\hline Procaviidae & & $\begin{array}{l}\text { Heterohyrax brucei } \\
\text { (yellow spotted hyrax) } \\
\text { Procavia capensis (rock hyrax) }\end{array}$ \\
\hline Leporidae & & Lepus habessinicus (Abyssinian hare) \\
\hline Orycteropodidae & & Orycteropus afer (aardvark) \\
\hline Canidae & & $\begin{array}{l}\text { Lycaon pictus } \\
\text { (African wild dog) } \\
\text { Otocyon megalotis (bat-eared fox) } \\
\text { Canis adustus (side-striped jackal) } \\
\text { Canis aureus (golden jackal) } \\
\text { Canis mesomelas (black-backed jackal) }\end{array}$ \\
\hline Viverridae & & $\begin{array}{l}\text { Genetta genetta (common genet) } \\
\text { Viverra civettina (civet) }\end{array}$ \\
\hline Herpestidae & & $\begin{array}{l}\text { Helogale hirtula } \\
\text { (desert dwarf mongoose) } \\
\text { Helogale parvula (dwarf mongoose) } \\
\text { Herpestes ichneumon } \\
\text { (Egyptian mongoose) } \\
\text { Galerella sanguinea (slender mongoose) }\end{array}$ \\
\hline Hyaenidae & & $\begin{array}{l}\text { Hyaena hyaena (striped hyena) } \\
\text { Crocuta crocuta (spotted hyena) }\end{array}$ \\
\hline Felidae & Felinae & $\begin{array}{l}\text { Acinonyx jubatus (cheetah) } \\
\text { Felis silvestris (wild cat) } \\
\text { Leptailurus serval (serval) } \\
\text { Caracal caracal (caracal) }\end{array}$ \\
\hline & Pantherinae & $\begin{array}{l}\text { Panthera pardus (leopard) } \\
\text { Panthera leo (lion) }\end{array}$ \\
\hline
\end{tabular}

members of the Kibish Formation. Consistent with its short depositional history, Member II is devoid of faunal samples, and is missing from the stratigraphic sequence in many places across the landscape, so faunal-bearing localities derive from Members I, III, and IV. Most of the fossils were collected from the surface, and because of topographic relief in the area, there are many places where several members overlie one another, creating ambiguity about the assignment of some specimens to a specific member. This is particularly problematic for specimens found at localities where Member III unconformably overlies Member I. In such situations, many of these fossils appear to have come from extensive aprons of dark sediments at the base of Member III. Generally, we counted specimens found in such contexts as deriving from Member III. Sampling of the different members of the formation was not uniform. Efforts concentrated on Member I because of the focus of the project on hominins from that member. In addition, exposures of Member I are of relatively low relief and are thus readily accessible.

The collection procedure followed different strategies, yielding differences in the completeness, identifiablity, and taxonomic category of each specimen. With bovids and equids, the focus was mainly on crania, horn cores, mandibles, and isolated teeth. Postcranial bones were collected, but tarsals such as astragali and calcanei were especially targeted. Faunal remains of all non-ungulate taxa were always collected due to their rarity. Only the diagnostic dental remains and horn cores that were identified to family or more specific taxonomic ranks were included in the analyses presented here. Illustrations and other information about the Kibish mammalian fauna analyzed in this paper may be found at: http://turkanabasin.org/research/omo-kibish.

Taxonomic identification of most of the specimens, in particular the isolated teeth, benefited from the use of a digital archive on extant east African large mammals, developed by Assefa (http:// ripley.si.edu/hop/dentition/dentition.htm). Information calculated from the fauna of the Kibish localities included number of identifiable specimens (NISP) and minimum number of individuals (MNI). In quantifying the latter, we took specimens from each locality as separate individuals. The sums of MNIs from localities associated with each member provide the MNI value of specific taxa within a given member. For example, we have a total of 13 NISP of Syncerus caffer that were recovered from localities Kib-53, Kib-69, Kib-93, Kib-141, Kib-149, Kib-150, Kib-152, and Kib-106. Except for locality Kib-106, which has yielded six nonidentical specimens identified to Syncerus caffer, each of the other seven localities is represented by single specimens. Lumping the former six specimens from Kib-106 as one, Syncerus caffer's MNI for Member I is eight. This same procedure was applied to all levels of taxonomic identification, which comprises species, uncertain species (cf.), genus, and tribal levels.

The estimates of MNIs at the species level included only specimens that were securely identified. Specimens that were tentatively identified to a species (cf.) were added to the MNI only if there were no specimens of more than a single species of the same genus securely identified to species. In conditions where we have the representation of both securely and tentatively identified specimens, such as Kobus cf. K. ellipsiprymnus and Kobus ellipsiprymmus, only the latter counts was included in the MNI calculations. This procedure of calculating MNI follows mainly Bobe and Eck's (2001) approach, which was designed to control for the possibility of counting one individual more than once.

For comparative analysis of the Kibish fauna with extant and fossil specimens, it was necessary to modify the level of taxonomic abundance to the level of genus or tribe. The MNIs for genus and tribe were derived following the same approach cited above. The sum of MNI counts for each species of the same genus provides the MNI for that genus. Similarly, the tribal MNI is the sum of MNIs of all genera from the same tribe.

The faunal data were placed in a data matrix to evaluate representation and abundance of major taxonomic groups within and among the three members. Diversity indices were employed 
to assess the diversity of fauna among members. Differences and similarities in the patterns of faunal representations among the different members were further examined using chi-square goodness-of-fit tests. Similarly, univariate, bivariate, and correspondence analyses were employed for reconstructing past habitats of the Omo Kibish area using extant faunal data gathered from several modern game parks throughout Africa. We used correspondence analysis to evaluate integrated patterning (in terms of abundance) of various adaptations among habitats, and to determine into which type of habitat(s) the faunal data from Kibish best fit. Correspondence analysis (CA) is an exploratory tool for comparing Kibish faunal assemblages with modern faunal communities from a variety of habitats. As with any multivariate technique, the algorithm reduces large numbers of variables to two or three dimensional vectors so that they can be graphically displayed to better understand underlying patterns in the input data. Here, we used the generic distribution of taxa in habitats for the first CA; for the second CA, we used the adaptations exhibited by those taxa. As much of the variation in the data is placed on the first axis, this variation is expressed as a deviation from an expected chi-square value and described as inertia away from this expectation. The localities that plot close together in two-dimensional space are most similar to each other in the pattern represented by the genera or adaptations, whereas the genera or adaptations plot together based on the habitats from which they derive.

\section{Results}

\section{Fossil fauna}

In general, fauna collected from all members of the Kibish Formation are the same diverse species of large mammals, with most taxa known throughout the later-middle and late Pleistocene (Table 2). There are also some large mammalian taxa that show sporadic representation among the three Kibish members. The majority of large mammals represented in the Omo Kibish assemblage are the same as the extant fauna in the study area. There is not a single fossil specimen unambiguously identified to an extinct species. Because of the small sample sizes, we doubt that the faunal assemblages from any member are sufficiently large to sample all taxa that might have been present, especially rarer species such as carnivores and tubulidentates. While the absence of extinct taxa, in particular from Member I, suggests exclusive representation of extant taxa in the later-middle Pleistocene deposits of the Kibish Formation, we cannot be sure at this juncture if this is the case. Representations of only extant fauna, however, are documented from the middle Pleistocene fossil collections at Lainyamok, Kenya (Potts and Deino, 1995), and thus this pattern may indeed be the case at Kibish as well.

Fauna from the Kibish Formation includes taxa not often recovered from east African fossil localities, such as Cephalophus and Hylochoerus meinertzhageni. Both taxa are found in forest habitats with dense vegetation cover, which is likely why they have limited representation in the fossil record. The $H$. meinertzhageni specimens (Fig. 2), in particular, are rare and listed in the Paleobiology Database ${ }^{1}$ as occurring only at Kaiso (Uganda), Matupi Cave (Democratic Republic of Congo), and Lamto Station (Cote d'ivore). Uncertain Hylochoerus remains have also been reported from Kanjera, Kenya (Plummer et al., 1994). All of the confirmed fossil Hylochoerus remains come from sites located within the tropical rainforest belt or its fringes. In its modern-day distribution, the

\footnotetext{
${ }^{1}$ The data were downloaded from the Evolution of Terrestrial Ecosystems (ETE) database on 15 June 2002 using the group name "mammal" and the following parameters: middle and late Pleistocene, Africa.
}

species has a preference for forests and forest mosaics. Occurrence of this suid species with faunal remains from Kibish is consistent with a closed, wet habitat.

Reliable identification of two different equids based exclusively on the distinct morphology of their dentitions is often problematic. This is particularly so for isolated teeth, which constitute the majority of the equid sample from Kibish. As noted above, the Omo area is one of the few regions where Equus burchellii and E. grevyi are sympatric, a distributional pattern that may extend deep into the Quaternary. In addition, to morphologically distinguish the Kibish equid species from one another, we measured the occlusal length and breadth of 52 (20 Equus grevyi and 32 E. burchellii) maxillary and mandibular dentitions housed in the National Museum of Natural History (Smithsonian Institution) for comparison. Differences in the occlusal length of most of the cheek teeth of these equids were noted and these were used in conjunction with distinctive morphological features to differentiate $E$. grevyi from $E$. burchellii.

In general, the faunal samples from Kibish document considerable diversity of large mammals, with ungulates predominant throughout the sequence. Primates and carnivores are poorly represented, and we do not believe that this is due to taphonomic factors because of the recovery of even smaller mammals such as Thryonomys, Hystrix, and Heterocephalus in the assemblages. Extant and fossil faunas from the Kibish show considerable overlap, particularly among bovids. The exceptions are the lack of some bovid taxa, such as Taurotragus, Litocranius, and Oreotragus in the fossil record. Among nonbovid ungulates, there are a few remains of Ceratotherium simum, the white rhino. Damaliscus cf. $D$. niro remains from an unrecorded locality represent the only extinct large mammal in the assemblage. Because of contextual uncertainty, this specimen can neither be incorporated into the analysis nor taken as evidence for the presence of an extinct taxon in the Kibish assemblage.

Cephalophus and Hylochoerus meinertzhageni are not found in the Kibish area today. The only primate specimen, a complete skull of Papio cf. P. anubis, comes from the uppermost member of the formation. The 1967 expedition to Kibish by the National Museums of Kenya recovered two additional primate specimens, including a partial skull identified as Colobus sp. (S. Frost, personal communication). However, we are unsure of the exact provenience of this specimen within the formation and so have not included it in further analyses.

Table 2 summarizes the numbers of identified specimens (NISP) in each member. The sample from Member I (118) is considerably larger than the samples from Members III (39) and IV (22). Overall, the limited sample sizes from all members, particularly Members III and IV, do not allow definitive conclusions regarding the absence of taxa in the faunal assemblage. Despite noticeable differences in the occurrence and abundance of fossil taxa among the three members, the concentration of efforts on surveying Member I may partly account for observed sample-size differences.

Throughout all members, bovids constitute more than $60 \%$ of the faunal sample at each stratigraphic level. Among nonbovids, equids and suids are well represented, whereas primates and carnivores make up only a small portion of the assemblage; these taxa are therefore low in both diversity and abundance. Small sample sizes, particularly in the upper two members, do not allow a reliable estimate of differences or similarities in faunal abundances among the three members.

In reviewing the presence and absence of different mammalian taxa from each member, no conspicuous difference in overall pattern of faunal representations was noted. Chi-square tests for goodness-of-fit conducted on three species, selected for their large sample sizes, also show a lack of significant differences among members. Results from these tests are: Phacochoerus africanus, $\chi^{2}$ 
Table 2

List and abundance of faunal remains from the Kibish Formation

\begin{tabular}{|c|c|c|c|c|c|c|}
\hline \multirow[t]{2}{*}{ Family } & \multirow[t]{2}{*}{ Subfamily/tribe } & \multirow[t]{2}{*}{ Genus and species } & \multicolumn{4}{|c|}{ Members } \\
\hline & & & I & III & IV & Unspecified* (NISP) \\
\hline \multirow[t]{30}{*}{ Bovidae } & Alcelaphini & Alcelaphini indet. & $5(7)$ & & $1(3)$ & \\
\hline & & Alcelaphus sp. & 1 & & & \\
\hline & & cf. Damaliscus & & 1 & & \\
\hline & & Damaliscus cf. D. niro* & & & & 1 \\
\hline & Cephalophini & Cephalophini indet. & $1(2)$ & & & \\
\hline & & Cephalophus cf. C. weynsi & $1(3)$ & & & \\
\hline & Neotragini & Madoqua sp. & 1 & 1 & & 7 \\
\hline & & Madoqua cf. M. guentheri & & 1 & & 1 \\
\hline & & Madoqua cf. M. kirkii & $3(10)$ & & & \\
\hline & Reduncini & Reduncini indet. & & & 1 & \\
\hline & & cf. Kobus & $1(2)$ & 1 & 1 & 2 \\
\hline & & Kobus sp. & & 1 & & \\
\hline & & Kobus cf. K. ellipsiprymnus & 2 & $1(3)$ & $3(4)$ & 3 \\
\hline & & Kobus ellipsiprymnus & 3 & 3 & 2 & 5 \\
\hline & & Redunca sp. & 2 & & & \\
\hline & & Redunca cf. $R$. redunca & & & 1 & 1 \\
\hline & & Redunca redunca & 1 & & & 1 \\
\hline & Antilopini & Antilopini indet. & 1 & & & 1 \\
\hline & & Gazella sp. & 1 & & & 1 \\
\hline & Hippotragini & Hippotragini indet. & & 1 & 1 & \\
\hline & & Oryx cf. O. gazelle & 1 & 1 & 3 & \\
\hline & Tragelaphini & Tragelaphini indet. & 1 & & & \\
\hline & & Tragelaphus strepsiceros & 1 & 1 & & \\
\hline & & Tragelaphus cf. T. strepsiceros & & 1 & & \\
\hline & & Tragelaphus cf. T. scriptus & $6(7)$ & 1 & & \\
\hline & & Tragelaphus scriptus & 5 & $2(3)$ & & \\
\hline & Bovini & Bovini indet. & 7 & 3 & 2 & 5 \\
\hline & & Syncerus caffer & $9(14)$ & $5(10)$ & $6(7)$ & 13 \\
\hline & & Syncerus cf. S. caffer & & 1 & & 1 \\
\hline & Aepycerotini & cf. Aepyceros & & & & 2 \\
\hline Hippopotamidae & & Hippopotamus amphibius & $9(10)$ & 3 & $3(5)$ & 9 \\
\hline \multirow[t]{3}{*}{ Suidae } & & Phacochoerus africanus & $9(22)$ & 6 & $4(8)$ & 6 \\
\hline & & Hylochoerus meinertzhageni & & 2 & & \\
\hline & & Potamochoerus porcus & & 1 & & \\
\hline Giraffidae & & Giraffa camelopardalis & 3 & & 1 & 3 \\
\hline \multirow[t]{3}{*}{ Equidae } & & Equus sp. & $4(8)$ & & & \\
\hline & & Equus cf. E. grevyi & $1(2)$ & & 1 & 4 \\
\hline & & Equus cf. E. burchellii & 2 & & & \\
\hline Elephantidae & & Loxodonta africanus & & 1 & 1 & \\
\hline Rhinoceratidae & & Ceratotherium simum ${ }^{*}$ & & & & 4 \\
\hline Thryonomyidae & & Thyonomys swinderianus & 3 & 1 & & 1 \\
\hline Hystericidae & & Hystrix cristata & 1 & & & \\
\hline Bathyergidae & & Heterocephalus & 1 & & & \\
\hline Herpestidae & Herpestinae & Herpestes & & 1 & & \\
\hline Hyaenidae & & Hyaena hyaena & & 1 & & \\
\hline Cercopithecidae & Cercopithecinae & Papio cf. P. anubis & & & 1 & \\
\hline
\end{tabular}

* Faunal samples from locations that could not be identified to a specific member.

(2, $n=19)=2, \quad p>0.05 ;$ Syncerus caffer, $\chi^{2}(2, \quad n=20)=1.3$, $p>0.05$; and Hippopotamus amphibius, $\chi^{2}(2, n=15)=4.8, p>0.05$.

Notwithstanding the possible effects of small sample size and a biased sampling strategy, the fauna from Member IV reflects a paucity of some bovid tribes (Fig. 3), such as Tragelaphini, Cephalophini, Neotragini, and Antilopini, almost all of which appear to be more abundant in Member I and, to some degree, Member III. On the other hand, the abundances of Oryx cf. O. gazella and Kobus ellipsiprymnus show moderate increases in Member IV.

Sample size is greater for Member III than for Member IV, and the faunal diversity is also slightly higher. Despite differences in abundance, bovid species representation in Member III is similar to that in Member I. Member III lacks equids, but three species of suids (Phacochoerus africanus, Hylochoerus meinertzhageni, and Potamochoerus porcus) were documented only from this member. Phacochoerus is the best-represented species of suid throughout the sequence at Kibish.

For reasons cited earlier, the composition and abundance of fauna from Member I is considerably higher than that of the two overlying members. Cephalophus and Giraffa are known exclusively from Member I. In addition to Syncerus caffer and Phacochoerus africanus, the faunal sample from Member I includes abundant remains of Hippopotamus amphibius. In Members III and IV, S. caffer and $P$. africanus show higher representations, respectively, in comparison to Member I.

\section{Paleoecological reconstruction}

Researchers employ different methods of paleofauna-based environmental reconstructions. These include the taxon-based (phylogenetic) approach (Vrba, 1980; Dodd and Stanton, 1990), the functional morphological (ecomorphological) approach (Plummer and Bishop, 1994; Kappelman et al., 1997; DeGusta and Vrba, 2003, 2005), and a method based on adaptation and community structure (ecological diversity) (Andrews et al., 1979; Reed, 1997, 1998; Mendoza et al., 2005). If we followed a taxonomic uniformitarian principle to reconstructing the environments at Kibish, then the presence of Cephalophus and Hylochoerus meinertzhageni would suggest closed-habitat environments in Members I and III. Rather than taxonomic uniformitarianism, however, we prefer an 


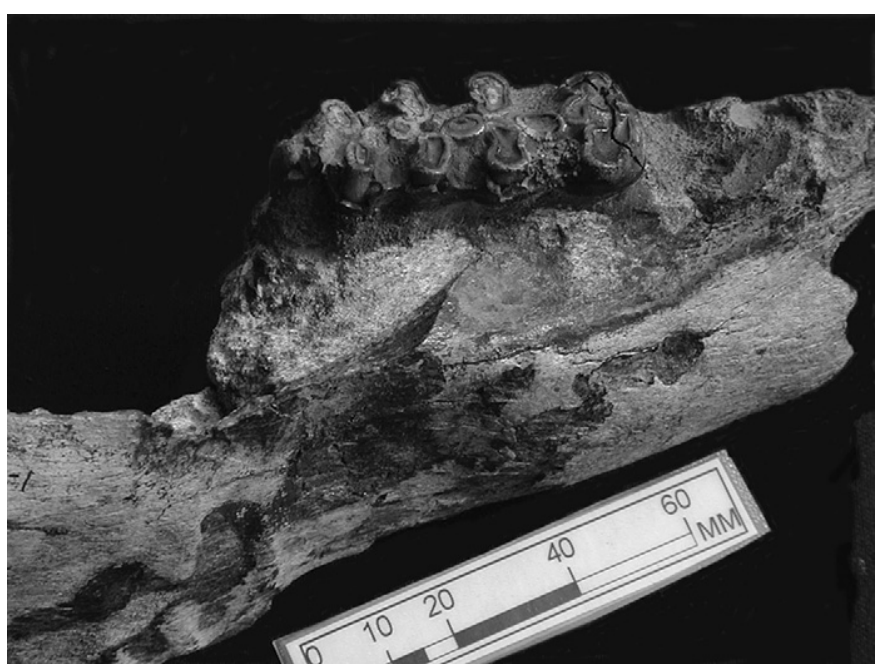

Fig. 2. Hylochoerus meinertzhageni (giant forest hog) mandible from Kibish.

ecological-diversity method because of its comprehensive community-based approach, which combines analysis of morphology and ecological adaptation of each taxon to suggest overall vegetation.

The ecological-diversity approach, as originally outlined by Andrews et al. (1979), assigns to each mammalian taxon trophic, locomotor (or substrate), and body-size attributes. Subsequent work by Reed $(1997,1998)$ expanded this approach, with a focus on the proportion of each adaptation within each habitat type (e.g., forests, closed woodlands, open woodlands, bushlands, shrublands, grasslands, and deserts). Reed's method used only trophic and substrate adaptations, and was limited to mammals greater than $500 \mathrm{~g}$ in size. The locomotor and trophic categories include five and twelve types, respectively (see Reed, 1997, 1998). Species in extant African mammal communities were assigned to substrate and trophic categories based on observations or stomach contents, and the percentage of species in each category of adaptation were calculated for each habitat. Univariate and bivariate methods of analysis were employed to differentiate vegetation types by the proportion of trophic and substrate adaptations. This method identifies ranges of adaptation percentages that predict habitats due to significant differences among habitats in those particular adaptations. These significantly different adaptations can then be implemented in reconstructing broad habitat types for fossil assemblages. Taking substrate adaptations as an example, high proportions of terrestrial mammals usually indicate more grassland-dominated vegetation, whereas high percentages of arboreal mammals are consistent with forest-dominated vegetation.

We classified the Kibish fossil fauna identified either to species or genus level with specific substrate and trophic adaptations assigned to each of the extant large mammals. We incorporated genera in our classifications only when there were no species of mammal identified in the member, and when the trophic and substrate adaptations were identical across all extant members of the genus (e.g., Giraffa). Table 3 shows the taxonomic percentages of large mammals from all members of the Kibish Formation sorted by their respective adaptations.

Figure 4 compares the faunal data from Kibish, divided by member, to the range of trophic and substrate adaptations across the six major vegetation types of Reed (1997). Some adaptations, such as arboreality and other locomotor and trophic variables, are excluded from the analysis because there were not any taxa from Kibish assigned to these specific categories. Adaptations showing discrete

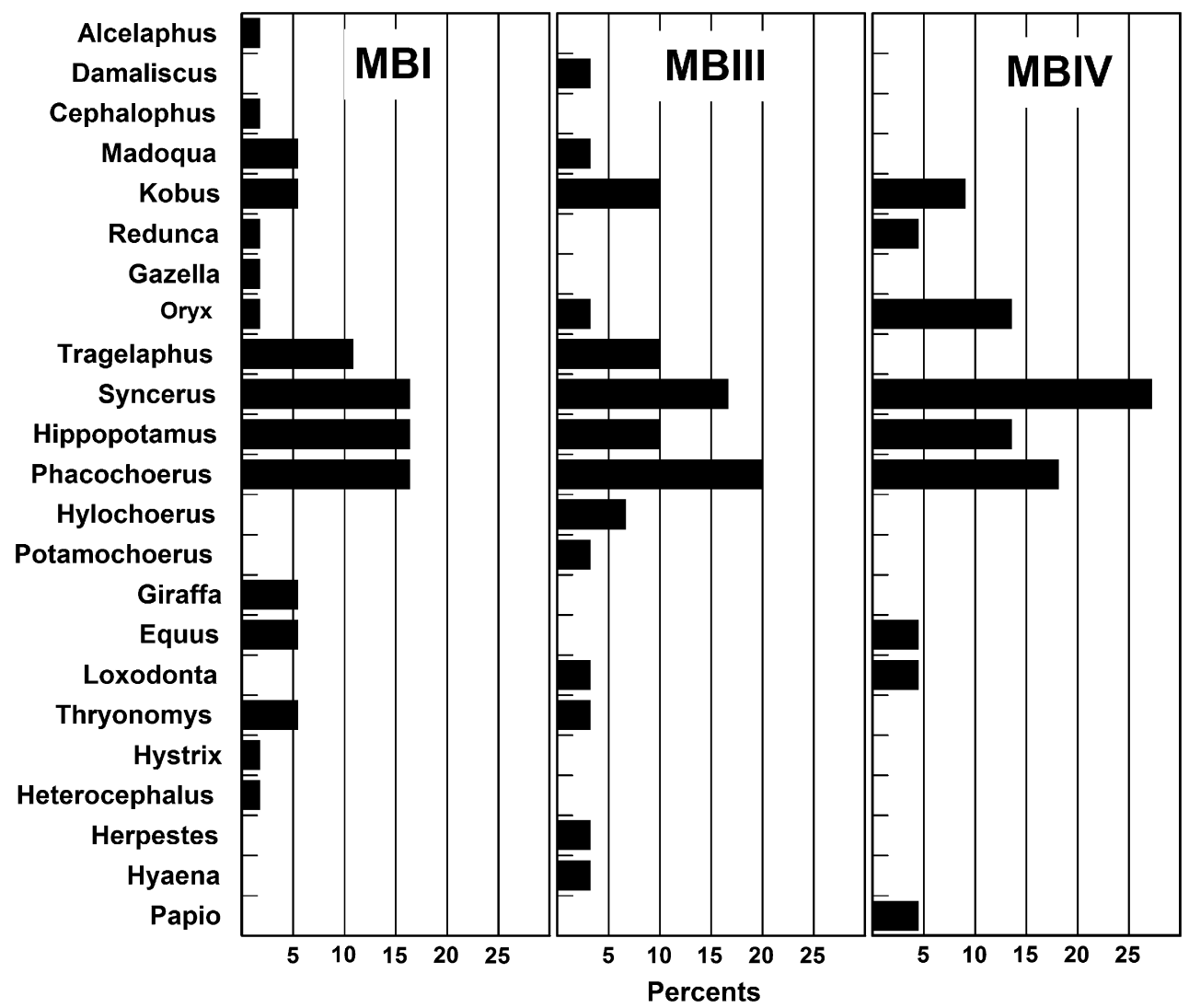

Fig. 3. Relative representation of large mammals by stratigraphic layer. 
Table 3

Abundance (percentage) of large mammals categorized by locomotor and trophic ecovariables

\begin{tabular}{|c|c|c|c|c|c|}
\hline \multirow[t]{2}{*}{ Taxon } & \multicolumn{3}{|c|}{ Member } & \multirow[t]{2}{*}{ Substrate } & \multirow[t]{2}{*}{ Trophic } \\
\hline & I & III & IV & & \\
\hline Alcelaphus & 1 & - & - & $\mathrm{T}$ & G \\
\hline Damaliscus & - & 1 & - & $\mathrm{T}$ & G \\
\hline Cephalophus cf. C. weynsi & 1 & - & - & $\mathrm{T}$ & FL \\
\hline Madoqua cf. M. guentheri & - & 1 & - & $\mathrm{T}$ & $\mathrm{B}$ \\
\hline Madoqua cf. M. kirkii & 3 & - & - & $\mathrm{T}$ & FL \\
\hline Kobus ellipsiprymnus & 3 & 3 & 2 & $\mathrm{~T}$ & FG \\
\hline Redunca redunca & 1 & - & - & $\mathrm{T}$ & FG \\
\hline Oryx cf. O. gazelle & 1 & 1 & 3 & $\mathrm{~T}$ & G \\
\hline Tragelaphus strepsiceros & 1 & 1 & - & $\mathrm{T}$ & B \\
\hline Tragelaphus scriptus & 5 & 2 & - & $\mathrm{T}$ & B \\
\hline Syncerus caffer & 9 & 5 & 6 & $\mathrm{~T}$ & MF \\
\hline Hippopotamus amphibius & 7 & 2 & 1 & $A Q$ & FG \\
\hline Phacochoerus africanus & 9 & 6 & 4 & $\mathrm{~T}$ & G \\
\hline Potamochoerus & - & 1 & - & $\mathrm{T}$ & $\mathrm{OM}$ \\
\hline Hylochoerus meinertzhageni & - & 2 & - & $\mathrm{T}$ & MF \\
\hline Giraffa camelopardalis & 3 & - & 1 & $\mathrm{~T}$ & B \\
\hline Equus cf. E. grevyi & 1 & - & 1 & $\mathrm{~T}$ & G \\
\hline Equus cf. E. burchellii & 2 & - & - & $\mathrm{T}$ & G \\
\hline Loxodonta africanus & - & 1 & 1 & $\mathrm{~T}$ & MF \\
\hline Thryonomys swinderianus & 3 & 1 & - & $\mathrm{T}$ & FG \\
\hline Hystrix & 1 & - & - & $\mathrm{F}$ & $\mathrm{R}$ \\
\hline Herpestes & - & 1 & - & $\mathrm{T}$ & $\mathrm{CI}$ \\
\hline Hyaena & - & 1 & - & $\mathrm{T}$ & $\mathrm{CB}$ \\
\hline Papio cf. P. anubis & - & - & 1 & $\mathrm{TA}$ & FL \\
\hline \multirow[t]{2}{*}{ Adaptations } & \multicolumn{5}{|c|}{ Member } \\
\hline & I & & & III & IV \\
\hline \multicolumn{6}{|l|}{ SUBSTRATE } \\
\hline A & 0.0 & & & 0.0 & 0.0 \\
\hline$A Q$ & 13.7 & & & 6.9 & 5.0 \\
\hline $\mathrm{F}$ & 2.0 & & & 0.0 & 0.0 \\
\hline $\mathrm{T}$ & 84.3 & & & 93.1 & 90.0 \\
\hline $\mathrm{TA}$ & 0.0 & & & 0.0 & 5.0 \\
\hline \multicolumn{6}{|l|}{ TROPHIC } \\
\hline $\mathrm{B}$ & 17.6 & & & 13.8 & 5.0 \\
\hline $\mathrm{CB}$ & 0.0 & & & 3.4 & 0.0 \\
\hline $\mathrm{CI}$ & 0.0 & & & 3.4 & 0.0 \\
\hline FG & 27.5 & & & 20.7 & 15.0 \\
\hline $\mathrm{FL}$ & 7.84 & & & 0.0 & 5.0 \\
\hline G & 27.45 & & & 27.6 & 40.0 \\
\hline MF & 17.64 & & & 27.6 & 35.0 \\
\hline OM & 0.0 & & & 3.4 & 0.0 \\
\hline $\mathrm{R}$ & 2.0 & & & 0.0 & 0.0 \\
\hline TC & 0.0 & & & 6.8 & 0.0 \\
\hline TF & 7.84 & & & 0.0 & 5.0 \\
\hline
\end{tabular}

Abbreviations are as follows: $\mathrm{A}=$ arboreal, $\mathrm{AQ}=$ aquatic, $\mathrm{F}=$ fossorial, $\mathrm{T}=$ terrestrial, $\mathrm{TA}=$ terrestrial/arboreal, $\mathrm{B}=$ browser, $\mathrm{CB}=$ meat/bone, $\mathrm{CI}=$ meat/invertebrates, $\mathrm{FG}=$ fresh grass, $\mathrm{FL}=$ fruit/leaves, $\mathrm{G}=$ grass, $\mathrm{MF}=$ leaves/grass, $\mathrm{OM}=$ omnivorous, $\mathrm{R}=$ roots/bulbs, $\mathrm{TC}=$ total carnivory, $\mathrm{TF}=$ total frugivory.

separation among habitats, as pointed out by Reed $(1997,1998)$, are restricted to arboreal substrate and total frugivory (a trophic strategy that combines the eating of fruit, fruit and insects, and fruit and leaves). The box plot towards the center of the figure shows discrete proportions of total frugivory in different vegetation zones compared with analogous data sets from Kibish. There are discrete differences in the abundance of total frugivory in different vegetation zones, with forests, different varieties of woodlands and bushlands, and grasslands showing high, medium, and low abundances, respectively. The data from Kibish approach values from extant grasslands and shrublands.

Other substrate and trophic adaptations also provide useful, though less specific, indications of habitat. Fossorial mammals tend to have higher representation in open rather than closed environments, and the fauna from Kibish lacks fossorial large mammals. The exception is Member I, which has a proportion close to what is expected for more closed habitats. On the other hand, most fossorial mammals are small- to medium-sized and therefore may be missing from our collection due to taphonomic bias. The other important substrate adaptation, aquatic, is obviously found wherever there is a river or lake, irrespective of specific terrestrial habitat. Therefore, the proportion of aquatic mammals in varying types of habitat shows considerable variation and overlap. Fauna from different members of the Kibish Formation include aquatic mammals, albeit in variable proportions, suggesting a type of habitat close to water. Likewise, the high proportion of fresh-grass grazers is closely associated with edaphic grasslands in lake margins, floodplains, river banks, and deltas. The proportion of freshgrass grazers from all members of the Kibish Formation is high, suggesting that edaphic grasslands associated with overbank flood deposits predominated.

Forest habitats are separated from other habitats because of the complete absence of grazers and meat/bone-feeding mammals, and relatively small abundances of terrestrial mammals. Excluding Member III, the Kibish faunal data represent a virtual lack of meat/ bone-feeding carnivores, such as hyaenids, showing a pattern consistent with forest-dominated habitat. Conversely, the representation of grazers and terrestrial mammals at Kibish is more closely aligned with what is documented from more open settings of grassland environments. As all meat/bone consumers are rare taxa in the fossil record, and the Kibish sample sizes are small, it is possible that these animals existed but are not represented in our fossil sample.

An interesting picture of Kibish habitats is evident in bivariate plots of two adaptations, such as total frugivory or fresh-grass grazing against total terrestrial substrate use (all substrate adaptations except arboreality) and fresh-grass grazing against aquatic substrate use. The percentages of fresh-grass grazing and aquatic locomotion (Fig. 5), as outlined by Reed (1998), separate edaphic grasslands from other vegetation types. Areas of abundant edaphic grasslands, floodplains, wetlands, and swamps are positioned in areas outside of the dotted box in Fig. 5. All data points derived from the Kibish fauna fall in areas well outside the dotted box. As stated above, there are no arboreal mammals documented securely from any specific member of the Kibish Formation. Therefore, total percentage of terrestrial mammals is $100 \%$ throughout the succession (although we know that Colobus sp. from Kibish was likely arboreal, we do not know its provenance). Despite high percentages of terrestrial mammals in the Kibish fauna, the degree of frugivore representation from all members, particularly Member I (7.84\%) and Member IV (5\%), suggests a grassland-dominated habitat (Fig. 6). The percentage of fresh-grass grazers from all members of Kibish is also high (ranging from $27.5 \%$ in Member I to $15.0 \%$ in Member IV), whereas the percentage of aquatic mammals is generally lower (Member I 13.7\%; Member III 6.9\%; Member IV $5 \%$ ). All members of the Kibish Formation feature habitats that include rivers, wetlands, and edaphic grasslands (Fig. 7). This is consistent with the earlier observation in the plot of percentage of fresh-grass grazing vs. aquatic locomotion.

In general, the bivariate plots comparing the fossil faunal communities from Kibish to extant faunal communities indicate mosaic habitats such as riparian forests and closed woodlands in combination with grasslands of mostly edaphic origin. Based on Reed's (1997) analysis of numerous Plio-Pleistocene faunal localities from southern and eastern Africa, the faunal communities from Kibish show close resemblance to communities from Kromdraai A (South Africa), the Okote and KBS Members of the Koobi Fora Formation (Kenya), and Swartkrans (Members 2 and 3; South Africa). In all of these localities, total percentage of terrestrial mammals is considerably high, while the percentages of frugivores and fresh-grass grazers are moderate. The percentages of freshgrass grazers from Kibish are often higher than those observed at the other Plio-Pleistocene localities, perhaps indicating more 

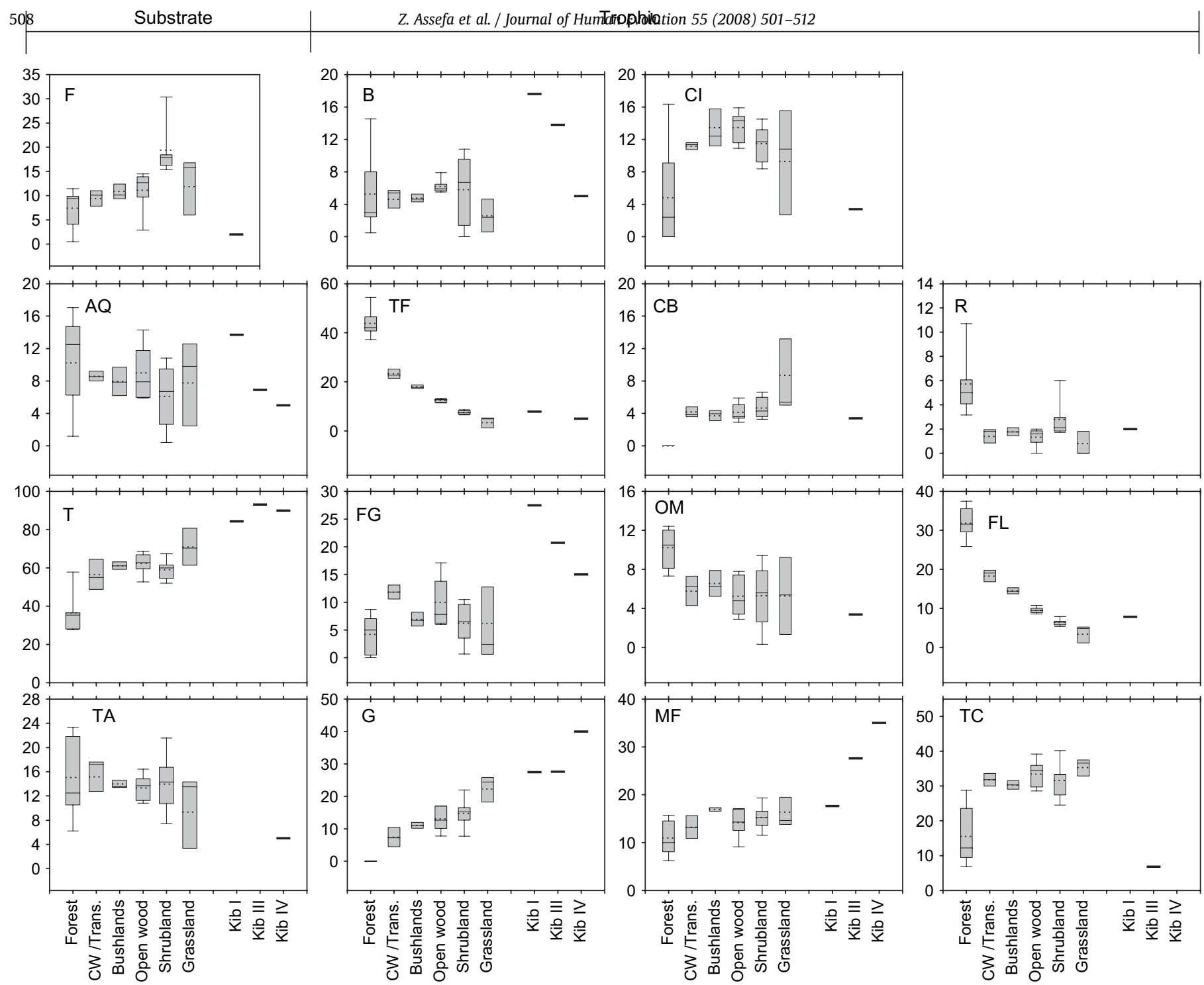

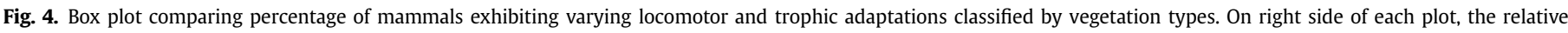
percentages of mammals from Kibish classified according to each adaptation are provided. Abbreviations are as in Table 3.

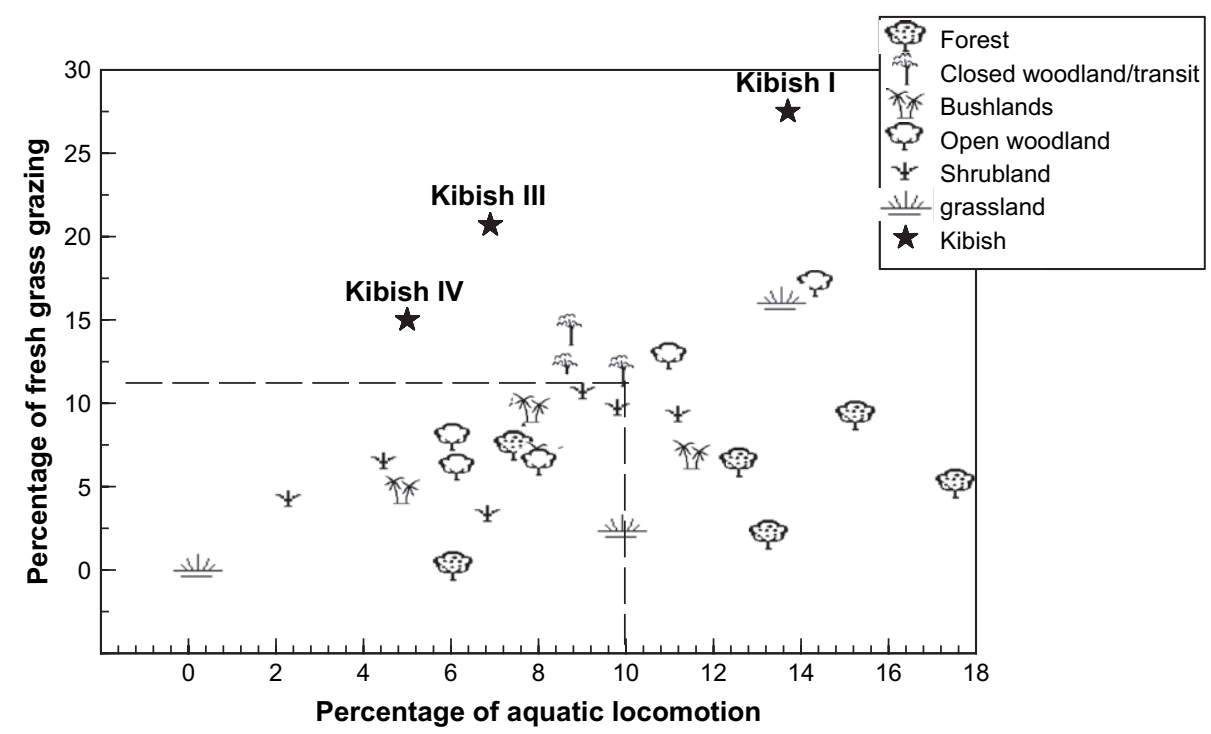

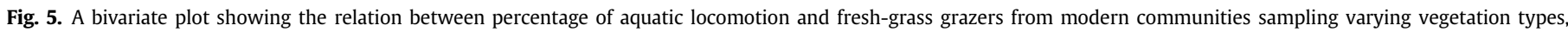

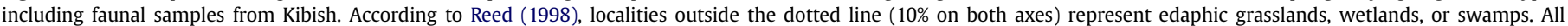
members from Kibish fall outside of the dotted range. 


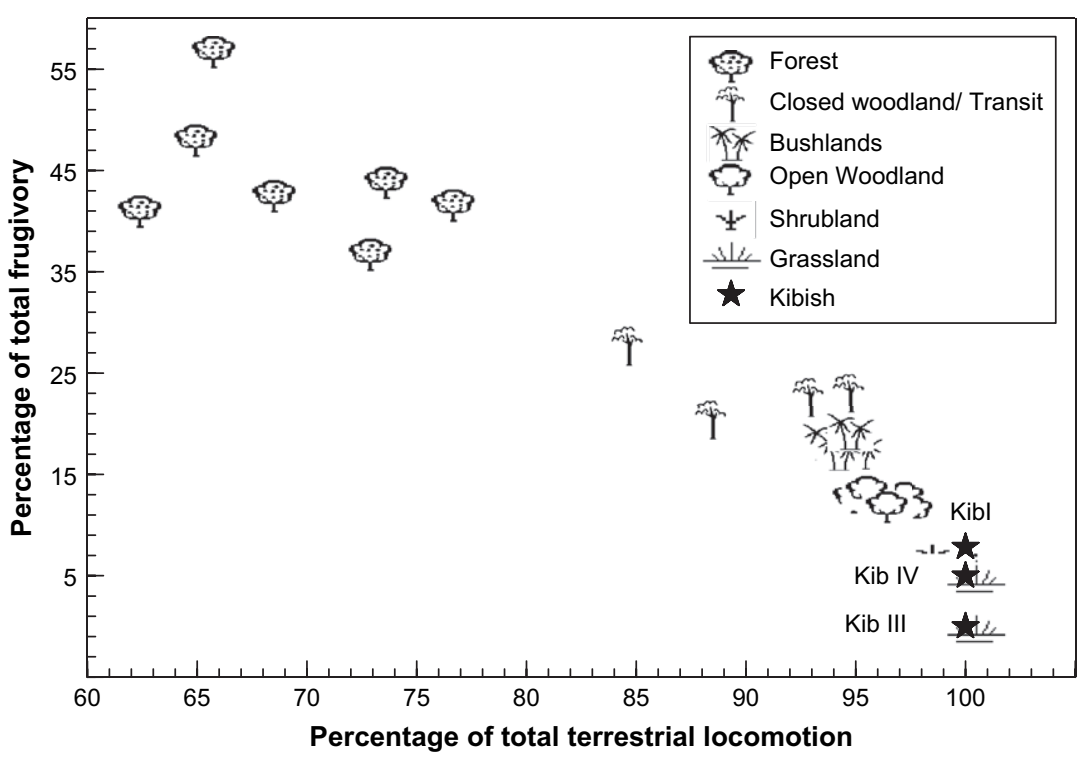

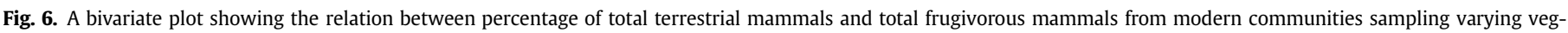
etation types, including faunal samples from Kibish.

widespread edaphic grassland. The small percentage of aquatic mammals recovered from all members is consistent with what is observed from Okote, which has been characterized as having edaphic grasslands of "shallow wetlands or marshy swamps" (Reed, 1997).

Further assessment of the Kibish faunal data in reference to extant communities provides a clearer picture of the above argument. Results of the correspondence analyses are illustrated in Fig. 8 (CA with all fauna in taxonomic groups) and Fig. 9 (CA only with fauna exhibiting diagnostic adaptations). The correspondence analysis illustrated in Figure 8 includes extant faunal communities (as row data) contrasted with the percentages of different taxonomic groups of mammals (as column data). Extant faunal data are from Reed (1998: Appendix 3). Axis 1 and axis 2 represent only $28.21 \%$ and $25.72 \%$ of the inertia, respectively. Such low axis values suggest that the space defined by the genera is not significant in the distribution of habitats, despite the moderate clustering by habitat of the modern localities.

None of the Kibish faunal localities show close association with extant localities of a particular habitat type. This is likely the result of the limited number of taxa recovered from these members, and it does not suggest a unique habitat for the ancient Kibish.

Conversely, in Fig. 9, the taxa are represented as community percentages of significantly different trophic and substrate adaptations, which accurately separate extant communities into habitats (Reed 1997, 1998). These adaptations include terrestrial, arboreal, aquatic, frugivorous, and fresh-grass-grazing mammals. The faunal data from Kibish were included to compare with the extant communities.

The total inertia represented on these two axes is $95.06 \%$ ( $80.54 \%$ and $14.52 \%$, respectively) and thus accounts for almost all of the variation among the extant communities. The Kibish faunal

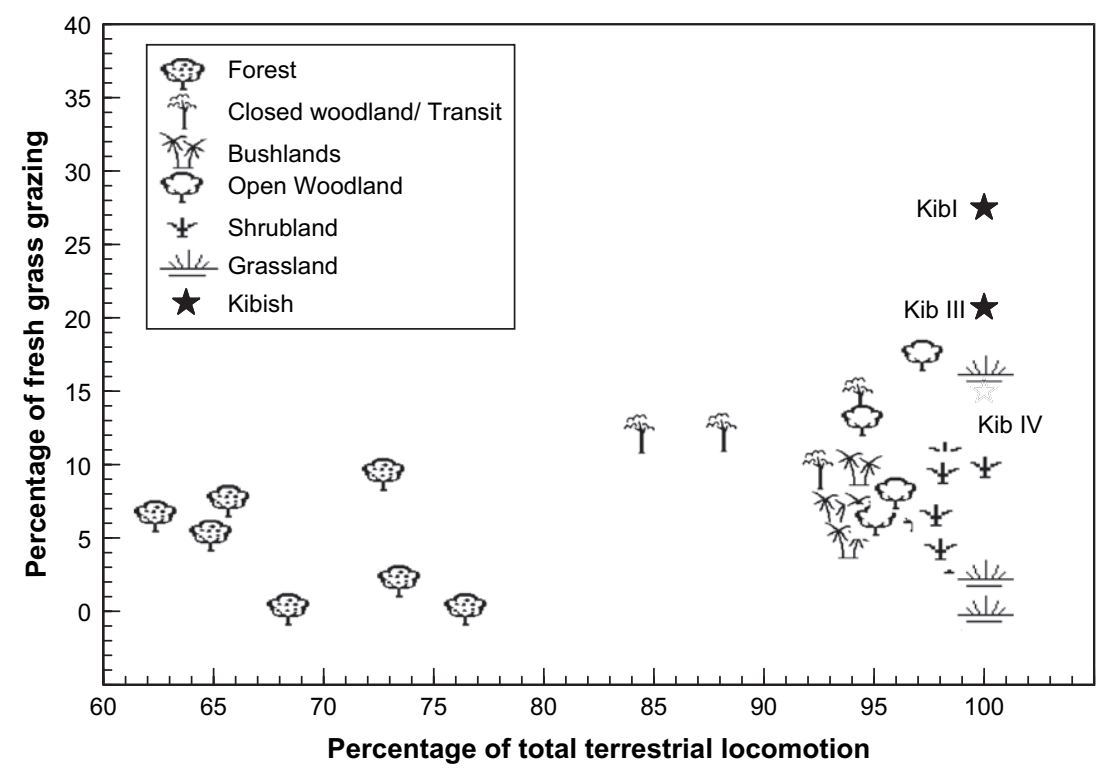

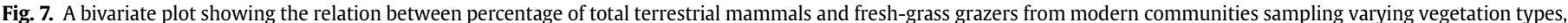
including faunal samples from Kibish. 


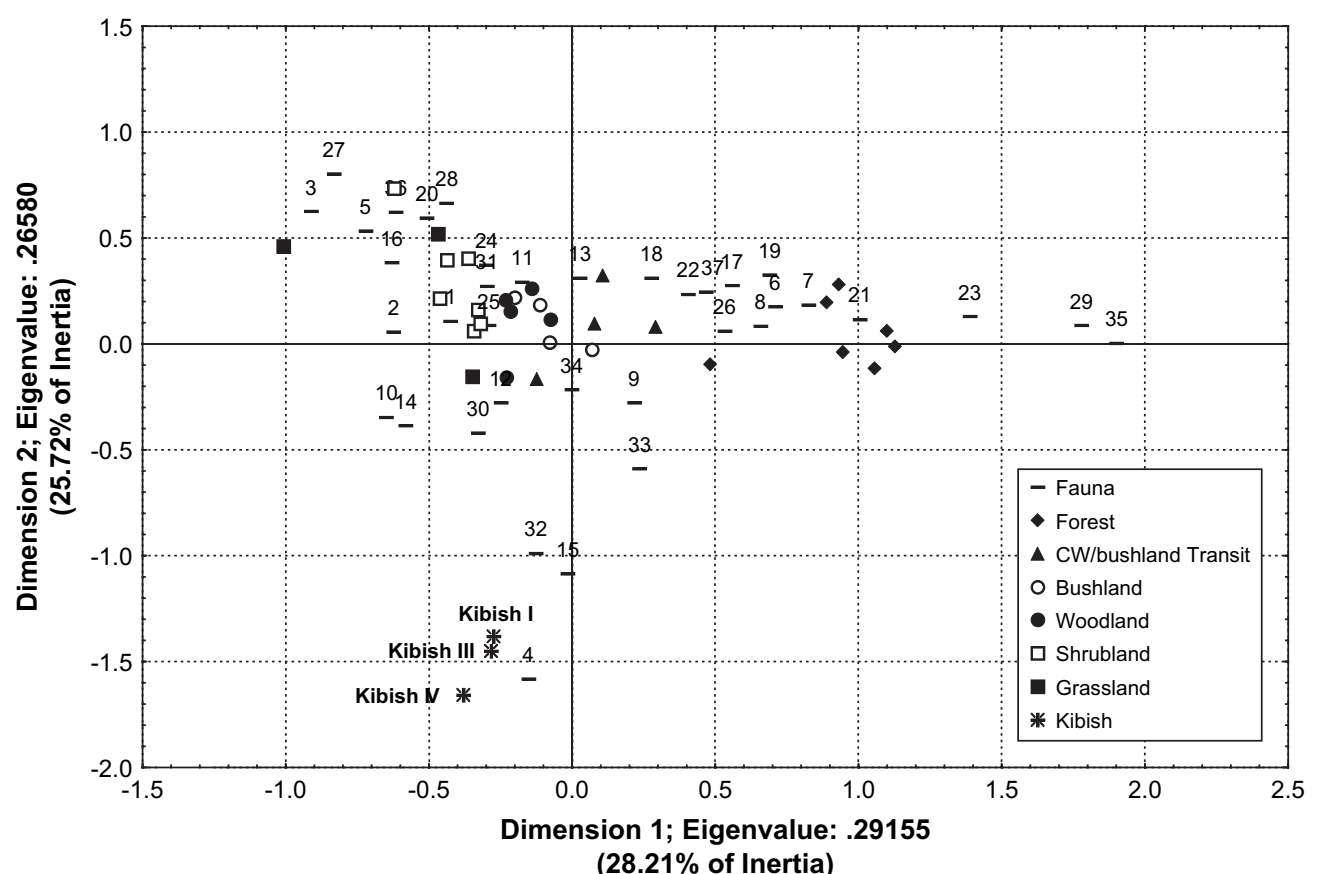

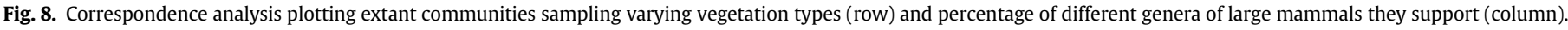
The Kibish faunal assemblages are included to show closely associated type(s) of vegetation and the related taxa of large mammals. Refer to Appendix 1 for abbreviations.

assemblages are now distributed with extant communities of grassland and shrubland, particularly those habitats possessing abundant water and edaphic grasslands, such as the Kafue Flats (central Zambia) and the Linyanti Swamp, with surrounding riverine woodland located just north of Okavango Delta in Botswana. Aquatic mammals and fresh-grass grazers are more abundant in these edaphic grassland and swampy regions. Therefore, the Kibish faunal assemblages also possess mammals exhibiting aquatic substrate use and fresh-grass grazing. These results support the view presented above that the Kibish faunal remains were deposited in an environment where edaphic grassland, shrubland, and riparian forests were dominant on a mosaic landscape. While there is no clear evidence of forest, as arboreal mammals are poorly represented in the assemblage, some of the rarer mammals (i.e., Cephalophus and Hylochoerus) recovered from the assemblage indicate a riparian forest.

As noted above, the Kibish fauna resembles that of the middle Pleistocene faunal assemblage from Lainyamok, Kenya, which also is composed entirely of extant species of large mammals, and suggests a close association with more open habitats such as

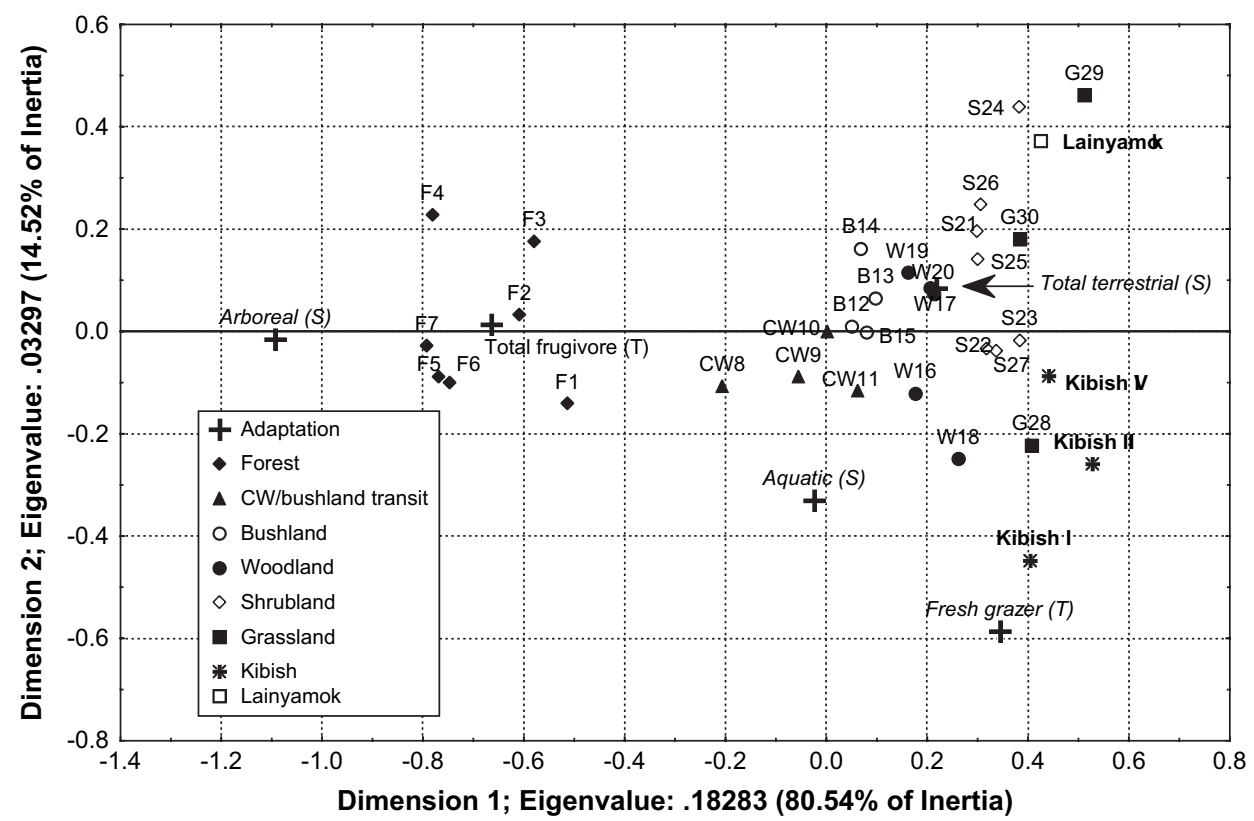

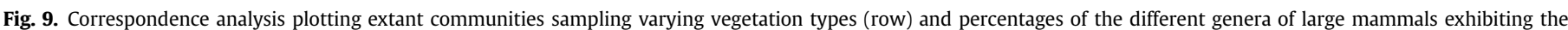

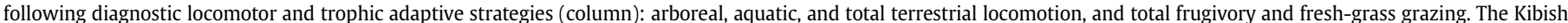
faunal assemblages are included to show the closely associated type(s) of vegetation identified by the diagnostic adaptations. Refer to Appendix 1 for abbreviations. 
shrublands and grasslands. In addition, the faunal remains from Lainyamok and Kibish share more similarities in their open-habitat-dominated faunal composition. However, differences between the two assemblages are also apparent, with the Kenyan assemblage showing more association with open-dry vegetation zones, such as Chobe and Serengeti plains, as opposed to the open-wet habitats that the Kibish faunal remains document. This is consistent with the predominantly deltaic environments that predominated in the Kibish area during the later Pleistocene. Sediments of the Kibish Formation were deposited over brief periods during wet phases of the late-middle and late Pleistocene (McDougall et al., 2005, 2008). Accordingly, faunal samples from different layers of the Kibish Formation represent only episodic records sampling the wet interglacial phases of the late-middle and late Pleistocene. Predominance of moist grasslands may also explain the lack of the large-bodied and hypsodont extinct taxa, such as Pelorovis, in the Kibish faunal assemblage. Dental and other morphological (locomotor, shape and size of horns) characteristics, paleoenvironmental associations, as well as the distribution of both large- and small-bodied extinct African late Pleistocene ungulates are consistent with dryforage specialization and adaptation to open environments (Klein, 1984; Marean, 1992). Such groups of ungulates must have been extremely rare or totally absent within the deltaic environments of the Kibish area, where moist vegetation types such as edaphic grassland were predominant.

\section{Conclusion}

The paleoecological reconstruction of the Omo Kibish deposits suggests a habitat that is very similar to that seen in the Omo Valley today, although moister and probably less arid further away from the river. Cephalophus and Hylochoerus live in forest environments where the vegetation cover is often dense and there is a regular supply of water. This conclusion is also indicated by the abundance of fossil fish (Trapani, 2008) and water birds (Louchart, 2008) recovered from the Kibish deposits. Mammalian taxa such as Thryonomys, diverse species of tragelaphines, and reduncines also suggest a more closed habitat, one with tall grasses and abundant standing water. There was also likely a variety of dense, light, and intermediate covers depending on soils and distance from the ancient Omo River. The Homo sapiens fossils from Kibish were also recovered from this mosaic habitat. It is evident that these hominins existed in landscapes extremely similar to extant habitats and with a fauna that still exists today in Africa. The fact that the Kibish fauna lacks carnivores and nonhuman primates is not an indication that these taxa (and other rarer and smaller mammals) were not present, but indicates the lack of mammals that were rare on the landscape in the Kibish sediment. Perhaps further excavation in additional areas of the Kibish Formation would provide a larger faunal community with which to analyze hominin interactions.

\section{Acknowledgements}

We are grateful to the Authority for Research and Conservation of Cultural Heritage (ARCCH) and the Ethiopian National Museum for granting us permits to study the deposits of the Omo Kibish area. Regional offices of the Ministry of Tourism and Culture provided all necessary assistance for the project. John Fleagle is responsible for the collection of the bulk of the faunal samples, and Denne Reed assisted with identification of some of the small mammals. Essayas G/Mariam assisted with the curation. Special thanks go to Curtis Marean for inspiring the revisit of the Kibish Formation 30 years after the initial exploration by Richard Leakey. Assefa thanks the Smithsonian's Human Origins and Archaeobiology
Programs for providing support during the analysis and writing of this paper. This paper was improved greatly by the comments and suggestions of René Bobe and Frank H. Brown.

\section{Appendix 1. Keys to abbreviations in Figs. 8 and 9}

\begin{tabular}{|c|c|c|c|}
\hline \multicolumn{2}{|l|}{ Figure 8} & \multicolumn{2}{|c|}{ Figure 9} \\
\hline 1 & Aepycerotini & F1 & East of Niger \\
\hline 2 & Alcelaphini & F2 & Congo Basin \\
\hline 3 & Antilopini & F3 & Knysna \\
\hline 4 & Bovini & F4 & Kilimanjaro \\
\hline 5 & Canidae & F5 & West of Niger \\
\hline 6 & Cephalophini & F6 & East of Cross \\
\hline 7 & Cercopithecini & F7 & Makakou \\
\hline 8 & Colobinae & CW8 & Rwenzori National Park \\
\hline 9 & Elephantidae & CW9 & Guinea Woodland \\
\hline 10 & Equidae & CW10 & Natal Woodland \\
\hline 11 & Felinae & CW11 & Lake Merwu \\
\hline 12 & Giraffidae & B12 & $\begin{array}{l}\text { West Lunga } \\
\text { National Park }\end{array}$ \\
\hline 13 & Herpestidae & B13 & Serengeti National Park \\
\hline 14 & Hippotragini & B14 & Serengeti Bush \\
\hline 15 & Hippopotamidae & B15 & Rukwa Valley \\
\hline 16 & Hyaenidae & W16 & Kafue National Park \\
\hline 17 & Hyracoidea & W17 & Kruger National Park \\
\hline 18 & Hystricidae & W18 & Linyanti Swamp \\
\hline 19 & Insectivora & W19 & SS Woodland \\
\hline 20 & Lagomorpha & W20 & Sudan \\
\hline 21 & Lorisidae & S21 & Southwest Arid \\
\hline 22 & Manidae & S22 & Kalahari TV \\
\hline 23 & Cricetinae & S23 & Sahel \\
\hline 24 & Mustelidae & S24 & Chobe \\
\hline 25 & Neotragini & S25 & Amboseli National Park \\
\hline 26 & Papionini & S26 & Tarangire National Park \\
\hline 27 & Pedetidae & S27 & Okavango \\
\hline 28 & Peleinae & G28 & Kafue Flats \\
\hline 29 & Pongidae & G29 & Serengeti Plains \\
\hline 30 & Reduncini & G30 & Southern savanna grassland \\
\hline 31 & Rhinocerotidae & & \\
\hline 32 & Suidae & & \\
\hline 33 & Thryonomidae & & \\
\hline 34 & Tragelaphini & & \\
\hline 35 & Tragulidae & & \\
\hline 36 & Tubulidentata & & \\
\hline 37 & Viveridae & & \\
\hline
\end{tabular}

\section{References}

Andrews, P., Lord, J.M., Nesbitevans, E.M., 1979. Patterns of ecological diversity in fossil and modern mammalian faunas. Biol. J. Linn. Soc. 11, 177-203.

Bauer, I.E., McMorrow, J., Yalden, D.W., 1994. The historic ranges of three equid species in north-east Africa: a quantitative comparison of environmental tolerances. J. Biogeogr. 21, 169-182.

Bobe, R., Eck, G.G., 2001. Responses of African bovids to Pliocene climatic change. Paleobiology 27 (Suppl. 2), 1-47.

Brown, F.H., Fuller, C.R., 2008. Stratigraphy and tephra of the Kibish Formation, southwestern Ethiopia. J. Hum. Evol. 55, 363-403.

Butzer, K.W., 1971. Recent History of an Ethiopian Delta. The University of Chicago, Chicago.

Carr, C.J., 1976. Plant ecological variation and pattern in the Lower Omo Basin. In: Coppens, Y., Howell, F.C., Isaac, G.L., Leakey, R.E.F. (Eds.), Earliest Man and Environments in the Lake Rudolf Basin. University of Chicago Press, Chicago, pp. 433-467.

Carr, C.J., 1998. Patterns of vegetation along the Omo River in southwest Ethiopia. Plant Ecol. 135, 135-163.

Cerling, T.E., Harris, J.M., Passey, B.H., 2003. Diets of East African Bovidae based on stable isotope analysis. J. Mammal. 84, 456-470.

DeGusta, D., Vrba, E., 2003. A method for inferring paleohabitats from the functional morphology of bovid astragali. J. Archaeol. Sci. 30, 1009-1022.

DeGusta, D., Vrba, E., 2005. Methods for inferring paleohabitats from discrete traits of the bovid postcranial skeleton. J. Archaeol. Sci. 32, 1115-1123.

Dodd, J.R., Stanton, R.J., 1990. Paleoecology: Concepts and Applications. Wiley, New York. 
Gagnon, M., Chew, A.E., 2000. Dietary preference in extant African Bovidae. J. Mammal. 81, 490-511.

Kappelman, J., Plummer, T., Bishop, L., Duncan, A., Appleton, S., 1997. Bovids as indicators of Plio-Pleistocene paleoenvironments in East Africa. J. Hum. Evol. 32, 229-256.

Klein, R.G., 1984. Mammalian extinctions and Stone Age people in Africa. In: Martin, P.S., Klein, R.G. (Eds.), Quaternary Extinctions: A Prehistoric Revolution. University of Arizona Press, Tucson, pp. 553-573.

Louchart, A., 2008. Fossil birds of Kibish Formation. J. Hum. Evol. 55, 513-520.

Marean, C.W., 1992. Implications of late Quaternary mammalian fauna from Lukenya Hill (south-central Kenya) for paleoenvironmental change and faunal extinctions. Quatern. Res. 37, 239-255.

McDougall, I., Brown, F.H., Fleagle, J.G., 2005. Stratigraphic placement and age of modern humans from Kibish, Ethiopia. Nature 433, 733-736.

McDougall, I., Brown, F.H., Fleagle, J.G., 2008. Sapropels and the age of the hominins Omo I and II, Kibish Formation, Ethiopia. J. Hum. Evol. 55, 409-420.

Mendoza, M., Janis, C.M., Palmqvist, P., 2005. Ecological patterns in the trophic size structure of large mammal communities: a "taxon-free" characterization. Evol. Ecol. Res. 7, 505-530.
Plummer, T.W., Bishop, L.C., 1994. Hominid paleoecology at Olduvai Gorge, Tanzania as indicated by antelope remains. J. Hum. Evol. 27, 47-75.

Plummer, T.W., Kinyua, A.M., Potts, R., 1994. Provenancing of hominid and mammalian fossils from Kanjera, Kenya, using EDXRF. J. Archaeol. Sci. 21, 553-563.

Potts, R., Deino, A., 1995. Mid-Pleistocene change in large mammal faunas of Eas Africa. Quatern. Res. 43, 106-113.

Reed, K.E., 1997. Early hominid evolution and ecological change through the African Plio-Pleistocene. J. Hum. Evol. 32, 289-322.

Reed, K.E., 1998. Using large mammal communities to examine ecological and taxonomic structure and predict vegetation in extant and extinct assemblages. Paleobiology 24, 384-408.

Trapani, J., 2008. Quaternary fossil fish from the Kibish Formation, Omo Valley, Ethiopia. J. Hum. Evol. 55, 521-530.

Vrba, E.S., 1980. The significance of bovid remains as indicators of environment and predation patterns. In: Behrensmeyer, A.K., Hill, A.P. (Eds.), Fossils in the Making: Vertebrate Taphonomy and Paleoecology. The University of Chicago Press, Chicago, pp. 247-271.

Yalden, D.W., Largen, M.J., Kock, D., 1984. Catalogue of the mammals of Ethiopia. 5. Artiodactyla. Monit. Zool. Ital. 19 (Suppl. 4), 67-221. 